\title{
FOSSIL LEAVES FROM THE CULLEN FORMATION (MIDDLE MIOCENE), TIERRA DEL FUEGO PROVINCE, ARGENTINA
}

\author{
NICOLÁS AUGUSTO CAVIGLIA \\ Museo Argentino de Ciencias Naturales "Bernardino Rivadavia", \\ Av. Ángel Gallardo 470 - C1405DJR, Buenos Aires, Argentina. \\ nicocavi09@gmail.com
}

\begin{abstract}
Fossil plants in the Tierra del Fuego Province, Argentinean Patagonia, are known since the expedition of Charles Darwin to the Beagle channel. However, only a few fossil plants have been described. In this work, a new fossil leaf collection is studied. It was collected from outcrops of the Cullen Formation (middle Miocene) located in the Atlantic coast of Tierra del Fuego, Patagonia, Argentina. Over two hundred pieces were collected in three localities: Cabo Espíritu Santo, Arroyo Beta, and Cañadón de los Mineros. The taxonomic studies reveal the presence of nine fossil species; six of them are related to Nothofagus Blume (Nothofagaceae), one to Myrtaceae, one to Gesneriaceae and the last one to the genus Podocarpus Labill. Our study agrees with previous ones, which suggested that the Nothofagaceae were dominant in the Cullen Formation area, and support the development of a cold temperate and humid forest in the area. The megafloral association studied result similar to others paleofloras developed in Patagonia during the Neogene, according to the cluster analysis performed. Finally, it was characterized like a Subantartic paleoflora sensu Troncoso \& Romero.
\end{abstract}

Keywords: megaflora, leaf imprints, Neogene, Patagonia.

RESUMO - As plantas fósseis da Província da Tierra del Fuego, Patagônia Argentina, são conhecidas desde a expedição de Charles Darwin sobre o Canal de Beagle. Entretanto, somente algumas poucas plantas foram descritas. No presente trabalho, uma nova coleção de folhas fósseis é estudada, coletadas de afloramentos da Formação Cullen (Mioceno médio) localizada na costa atlântica da Tierra del Fuego, Patagônia, Argentina. Cerca de duzentos espécimes foram coletados em três localidades: Cabo Espíritu Santo, Arroyo Beta e Cañadón de los Mineros. $\mathrm{O}$ estudo taxonômico revelou a presença de nove espécies fósseis, seis delas relacionadas a Nothofagus Blume (Nothofagaceae), uma a Myrtaceae, uma a Gesneriaceae e a última ao gênero Podocarpus Labill. Nosso estudo concorda com trabalhos prévios, que sugeriram que as Nothofagaceae foram dominantes na área da Formação Cullen, e suporta o desenvolvimento de um clima temperado frio e de floresta na área. A associação megaflorística estudada resulta ser similar a outras paleofloras desenvolvidas na Patagônia durante o Neógeno, de acordo com a análise de cluster realizada. Finalmente, ela foi caracterizada como uma paleoflora subantártica sensu Troncoso \& Romero.

Palavras-chave: megaflora, impressões de folhas, Neógeno, Patagônia.

\section{INTRODUCTION}

While phylogenetic and morphometric investigations are getting more important in the paleontological areas of vertebrates and invertebrates, paleobotanical studies in Argentina are mainly composed of illustrations and descriptions (Archangelsky, 2005). However, although the existence of fossil leaves in Patagonia is known since 19th century, most of the megafloras described in this area contain descriptions and/or illustrations that are outdated (Archangelsky, 2005; Ottone, 2005, 2011). In order to update the data, several of the Paleogene floras were reviewed and described again (Wilf et al., 2003; 2005; Iglesias et al., 2007; Vento \& Prámparo, 2018). In contrast, paleofloras developed during the Neogene were less studied so far (Table 1).
The knowledge of fossil leaves in the Tierra del Fuego Island, located in the southern Patagonia, Argentina, is known since Darwin's journey (1848). Despite this fact, few studies that include fossil leaves have been carried out in the area. Dusén (1899) established the first record, and described several Nothofagus leaves from localities of the Atlantic margin of the island. Then, Panti et al. (2008) defined different fossil leaves morphotypes from the Slogget Formation (upper Eocene-lower Oligocene), located south of the island of Tierra del Fuego. Finally, Caviglia $(2014,2017)$ studied two megafloral associations of the Cullen Formation and Barrancas Carmen Silva locality (middle Miocene).

The Cullen Formation is recognized at the north of Isla Grande de Tierra del Fuego (Figure 1), and has not been widely studied so far: Dusén (1899) described two Nothofagus 
Table 1. Early Neogene leaf floras from Patagonia.

\begin{tabular}{lll}
\hline Formation/Locality & Authors & Age \\
\hline Navidad Fm. & Troncoso (1991) & Upper Oligocene-middle Miocene \\
Río Leona Fm. & Cesari et al. (2015) & Miocene \\
Nirihuau Fm. & Fiori (1931, 1939, 1940), Romero \& Arguijo (1981), Caviglia \& Zamaloa (2014) & Miocene \\
Cullen Fm. & Durango de Cabrera \& Vergel (1989), Palma et al. (1992) & Miocene \\
Barrancas Carmen Silva locality & Dusén (1899) & Miocene \\
Santa Cruz Fm. & Brea et al. (2012) & Miocene \\
Arroyo de los Ciervos locality & Pujanaet al. (2015) & Miocene \\
\hline
\end{tabular}
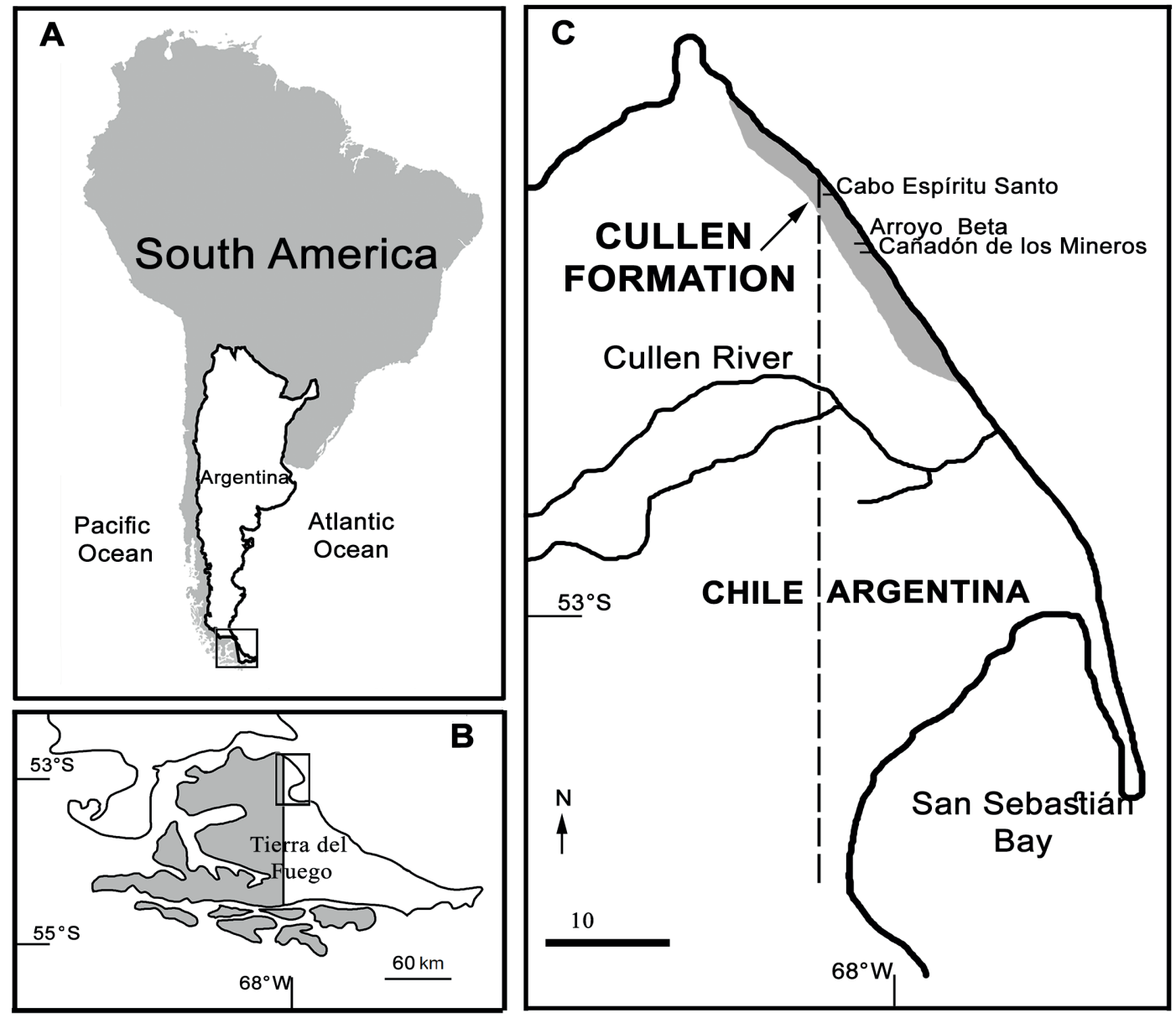

Figure 1. Geographical location of the Cullen Formation. A, Tierra del Fuego Island, southernmost South America, Patagonia. B, San Sebastián Bay, north of Tierra del Fuego Island. C, Cullen Formation and the three fossiliferous localities studied in the present work.

species, and Durango de Cabrera \& Vergel (1989) described three species of Nothofagus and Fagus integrifolia Dusén. Afterwards, Palma et al. (1992) mentioned the presence of fossil leaves related to Araucariaceae, Podocarpaceae, Nothofagaceae, Fagaceae and Myrtaceae, but did not publish descriptions or illustrations. Finally, Gandolfo (1994) described some fossil leaves of Nothofagus from the Cullen Formation in her doctoral thesis.

In contrast, the microflora of Cullen Formation has been studied in detail: Algae are represented by the families Botryocacacceae, Hydrodictyaceae and Zygnemataceae, whereas bryophytes are identified with representatives of Anthocerataceae, Bartramiaceae, Ricciaceae and Sphagnaceae. Nine families of ferns were recognized (Vergel \& Durango de Cabrera, 1988; Zamaloa \& Romero, 1990; Zamaloa, 1996; Zetter et al., 2000; Zamaloa 2004); Araucariaceae, Podocarpaceae and Cupressaceae among the conifers (Vergel \& Durango de Cabrera, 1988; Zamaloa \& Romero, 1990, 2005); angiosperm pollen grains allow the identification of 30 families (Vergel \& Durango de Cabrera, 1988; Zamaloa \& Romero, 1990; Zamaloa, 1999, 2000); and finally, six families of fungi have been recognized (García-Massini et al., 2004). The microfloral association is summarized in Table 2. 
Table 2. Cullen Formation families diversity. Based on Vergel \& Durango de Cabrera (1988), Durango de Cabrera \&Vergel (1989), Zamaloa \& Romero (1990, 1996, 2005), Zamaloa (1999, 2000, 2004), Zetter et al. (2000), García-Massini et al. (2004) and the present work.

\begin{tabular}{|c|c|c|c|}
\hline & Family & Palynomorphs & Leaves \\
\hline \multirow[t]{9}{*}{ Fungi } & Micropeltaceae & Plochmopeltinites (6 spp.) & - \\
\hline & Microthyraceae & Asterothyrites (1 sp.) & - \\
\hline & & Callimothalus (2 spp.) & - \\
\hline & & Microthyriella (1 sp.) & - \\
\hline & & Microthyrites (1 sp.) & - \\
\hline & & Pragmothyrites (3 spp.) & - \\
\hline & Perisporiaceae & Perisporiacites (1 sp.) & - \\
\hline & Trichopeltaceae & Trichopeltinites (1 sp.) & - \\
\hline & Trichothyriaceae & Trichothyrites (2 spp.) & - \\
\hline \multirow[t]{5}{*}{ Algae } & Botryocacacceae & Botryococcus (1 sp.) & - \\
\hline & Hydrodictyaceae & Pediastrum (1 sp.) & - \\
\hline & Zygnemataceae & Mougeotia (2 spp.) & - \\
\hline & & Spirogyra (3 spp.) & - \\
\hline & & Zygnema (1 sp.) & - \\
\hline \multirow[t]{5}{*}{ Bryophytes } & Anthocerataceae & Anthoceros (1 sp.) & - \\
\hline & Bartramiaceae & Coptospora (1 sp.) & - \\
\hline & Ricciaceae & Reboulisporites (1 sp.) & - \\
\hline & Sphagnaceae & Cingutriletes (1 sp.) & - \\
\hline & & Sphagnum (1 sp.) & - \\
\hline \multirow[t]{3}{*}{ Lycopods } & Isoetaceae & Isoetes (1 sp.) & - \\
\hline & Lycopodiaceae & Lycopodiumsporites (2 spp.) & - \\
\hline & & Lycopodium (1 sp.) & - \\
\hline \multirow[t]{11}{*}{ Ferns } & Adiantaceae & Currugatisporites (1 sp.) & - \\
\hline & Aspleniaceae/Dennstaedtiaceae & Tuberculatosporites (1 sp.) & - \\
\hline & Cyatheaceae & Cyathidites (1 sp.) & - \\
\hline & & Cnemidaria (1 sp.) & - \\
\hline & & Trichipteris (1 sp.) & - \\
\hline & Dicksoniaceae & Cyatheacidites (1 sp.) & - \\
\hline & & Lophosoria (1 sp.) & - \\
\hline & Hymenophyllaceae & Baculatisporites (1 sp.) & - \\
\hline & Ophioglossaceae & gen. indet. & - \\
\hline & Osmundaceae & Osmunda (1 sp.) & - \\
\hline & Polypodiaceae & gen. indet. & - \\
\hline \multirow[t]{9}{*}{ Conifers } & Araucariaceae & Araucariacites (1 sp.) & gen. indet. \\
\hline & Podocarpaceae & Dacrycarpites (1 sp.) & Podocarpus (1 sp.) \\
\hline & & Lygistepollenites (1 sp.) & - \\
\hline & & Phyllocladidites (2 spp.) & - \\
\hline & & Podocarpidites (6 spp.) & - \\
\hline & & Trichotomosulcites (1 sp.) & - \\
\hline & & Dacrydium (1 sp.) & - \\
\hline & & Microcahrys (1 sp.) & - \\
\hline & Cupressaceae & gen. indet. & - \\
\hline Gnetales & Ephedraceae & Ephedratype (1 sp.) & - \\
\hline \multirow[t]{3}{*}{ Angiosperms } & Amaranthaceae & Chenopodipollis (2 spp.) & - \\
\hline & Anacardiaceae & Campnosperma (1 sp.) & - \\
\hline & Apiaceae & gen. indet. & - \\
\hline
\end{tabular}


Table 2. Cont.

\begin{tabular}{|c|c|c|}
\hline Family & Palynomorphs & Leaves \\
\hline & Azorella (1 sp.) & - \\
\hline Aquifoliaceae & Ilex (1 sp.) & - \\
\hline Araliaceae & gen. indet. & - \\
\hline Arecaceae & gen. indet. & - \\
\hline Asteraceae & Tubulifloridites (1 sp.) & - \\
\hline Berberidaceae & Berberis (1 sp.) & - \\
\hline Bignoniaceae & gen. indet. & - \\
\hline Bombacaceae & Bombax (1 sp.) & - \\
\hline \multirow[t]{2}{*}{ Caesalpinaceae } & Cassia (1 sp.) & - \\
\hline & "Margacolporites" (1 sp.) & - \\
\hline Celastraceae & Maytenus (1 sp.) & - \\
\hline Cunoniaceae & Tricolpites (1 sp.) & - \\
\hline Cyperaceae & Cyperaccoepollis (1 sp.) & - \\
\hline Empetraceae & Ericipites (1 sp.) & - \\
\hline Euphorbiaceae & gen. indet. & - \\
\hline Gunneraceae & Gunnera (3 spp.) & - \\
\hline \multirow[t]{2}{*}{ Haloragaceae } & Haloragacidites (1 sp.) & - \\
\hline & Myriophyllum (1 sp.) & - \\
\hline \multirow[t]{2}{*}{ Malvaceae } & Malvacearumpollis (1 sp.) & - \\
\hline & Malvacipollis (3 spp.) & - \\
\hline Menyanthaceae & Striasyncolpites (1 sp.) & - \\
\hline Misodendraceae & Misodendrum (1 sp.) & - \\
\hline \multirow[t]{2}{*}{ Myrtaceae } & Myrtaceidites (3 spp.) & “Myrcia” (1 spp.) \\
\hline & Myrceugenia (1 sp.) & - \\
\hline Nyctaginaceae & gen. indet. & - \\
\hline Nothofagaceae & Nothofagidites (11 sp.) & Nothofagus (6 spp.) \\
\hline \multirow[t]{3}{*}{ Onagraceae } & Corsinipollenites (1 sp.) & - \\
\hline & Crassiorites (1 sp.) & - \\
\hline & Fuchsia (1 sp.) & - \\
\hline Poaceae & Gruminidites (1 sp.) & - \\
\hline \multirow[t]{2}{*}{ Polygonaceae } & Glencopollis (1 sp.) & - \\
\hline & Roipites (1 sp.) & - \\
\hline \multirow[t]{2}{*}{ Proteaceae } & Granodiporites (1 sp.) & - \\
\hline & Proteacidites (6 spp.) & - \\
\hline Ranunculaceae & gen. indet. & - \\
\hline \multirow[t]{4}{*}{ Rosaceae } & Acaenasp. & - \\
\hline & Striatopollis (1 sp.) & - \\
\hline & ?Polylepis (1 sp.) & - \\
\hline & Rubus (1 sp.) & - \\
\hline Rubiaceae & Palaeocoprosnadites (1 sp.) & - \\
\hline \multirow[t]{2}{*}{ Sapindaceae } & Cupanieidites (1 sp.) & - \\
\hline & Serjania (1 sp.) & - \\
\hline Sterculiaceae & gen. indet. & - \\
\hline Typhaceae & Sparganiaceaepollenites (1 sp.) & - \\
\hline Winteraceae & Pseudowinterapollis (1 sp.) & - \\
\hline Gesneriaceae & - & gen. indet. \\
\hline
\end{tabular}


The main objective of this work is to expand the knowledge of the Cullen Formation megaflora on the basis of the new records obtained in three fossiliferous localities: Cabo Espíritu Santo, Arroyo de los Mineros and Cañadón Beta, and to analyze their composition.

\section{GEOLOGICAL FRAMEWORK}

\section{Cullen Formation}

The Cullen Formation was deposited in the Austral Basin, which extends east of the Patagonian Andes through the island of Tierra del Fuego (Russo et al., 1980). The basin consists of Cretaceous and Cenozoic deposits covering rocks of mainly Jurassic age, opposite the Patagonian fold and thrust belt and southern Andes Mountains.

On the Tierra del Fuego Island, the deposits located to the north of Bahía San Sebastián (Figure 1) were named at the beginning as "Cullen strata" by Petersen \& Methol (1948). Later, Codignotto \& Malumián (1981) formally defined the Cullen Formation, which includes the earlier mentioned outcrops, and those found on the northern coast of the island Tierra del Fuego, from the Chilean boundary to the Cullen River (Figure 1). It is constituted by green yellow siltstones and claystones, and fine intercalations of brown sandstones with conspicuous layers of tuff and charcoal (Palma et al., 1992). The Cullen Formation does not expose its base at any point, and its upper part is in erosive discordance with Pleistocene deposits (Palma et al., 1992; Zamaloa, 1999, 2004).

\section{Age}

The age of the Cullen Formation was a subject of controversy. Several authors located the unit in the Paleogene, but several others in the Neogene. Di Benedetto (1973) proposed an upper Oligocene age, while Codignotto \& Malumián (1981) proposed an upper Miocene-lower Pliocene age, both based on a palynomorph correlation with Chilean units (Dorotea and Filaret formations). According to the described microflora association, Vergel \& Durango de Cabrera (1988) assigned an upper Eocene-Oligocene age to this unit. However, more recent palynological studies proposed an Oligocene-Miocene limit age (Zamaloa 1999, 2000; Zamaloa \& Romero, 2004), or Miocene (GarcíaMassini et al., 2004). Finally, K/Ar dating was carried out in the tuffaceous layers of the unit, with result of $19.3 \pm 0.7$ $\mathrm{Ma}$, and placed the Cullen Formation in the middle Miocene (Caviglia, 2014).

\section{Depositional environment}

The Cullen Formation sediments were deposited mainly in a continental environment, with fluvial and lacustrine influence, although marine intercalations can be observed in the lower section exposed (Zamaloa 1999, 2000). It was proposed a woody-forested landscape, developed in a wide alluvial plain crossed by meandering rivers (Palma et al., 1992; Zamaloa, 2000). Palma et al. (1992) suggested that the sediments of the type section (Arroyo Beta locality) could represent a deltaic plain with fluvial facies associated with a low energy area. Zamaloa $(1999,2000)$ mentioned that the development of a diverse microflora could be due to the development of closed bodies of water, such as lakes and/or swamps, with facilitated the preservation of abundant organic material.

\section{MATERIAL AND METHODS}

The fossil plants here studied are impressions/compressions of isolated leaves. They were collected in different field trips between 1991 and 1992 by M.C. Zamaloa, E.J. Romero, M.A. Gandolfo and R. Palma. They are deposited at the Museo Argentino de Ciencias Naturales "Bernardino Rivadavia", Buenos Aires, Argentina, under the acronym BAPb.

Fossils were collected from three localities: Cabo Espíritu Santo, Arroyo Beta and Cañadón de los Mineros (Figure 1C). Arroyo Beta is the type locality of Cullen Formation, its section was illustrated and described by Palma et al. (1992), where it is shown that the level most abundant on fossil leaves come from the upper and middle strata. The Cabo Espíritu Santo and Cañadón de los Mineros sections are illustrated in Zamaloa (1999). In the section of Cañadón de los Mineros it can be seen that the levels with fossils come from the lower and upper strata, and in the Cabo Espíritu Santo from the lower strata.

The angiosperm leaves were described following the Manual of Leaf Architecture (Ellis et al., 2009). However, some terminology used, such as that referring to the course of the vein and their relative thickness (gauge), or the angle of divergence of the secondary veins, are based in Hickey (1973). The APG IV (2016) proposal for the classification of angiosperms was followed for the angiosperms, and Chase \& Reveal (2009) was followed for the gymnosperms. For open nomenclature, Bengston (1988) was followed. The material was observed under a Nikon SMZ800 binocular lens and photographed with a Panasonic DMC-ZS20 camera.

Finally, a cluster analysis was performed among all the megafloras developed during the early Neogene of Patagonia. A matrix of presence/absence of plant families vs. stratigraphic units was made (Appendix 1), and the Jaccard index was used. The analysis was performed in R Studio program (R Core Team, 2017).

\section{SYSTEMATIC PALEONTOLOGY}

\author{
GYMNOSPERMAE Lindley, 1830 \\ Subclass PINIDAE Chase \& Reveal, 2009 \\ Order ARAUCARIALES Gorozhankin, 1904 \\ Family PODOCARPACEAE Endlicher, 1847
}

Podocarpus Labillardière, 1806

Type species. Podocarpus latifolius (Thunberg) R. Brown ex Mirbel, 1825. 
Diagnosis. See Contreras-Medina et al. (2006, p. 116).

\section{Podocarpus sp. 1}

(Figures 2M-O)

\section{Studied material. $\mathrm{BaPb} 16641$.}

Locality, unit and age. Cañadón de los Mineros, Tierra del Fuego, Cullen Formation. Argentina, middle Miocene.

Description. Fragment of branch in axial view, with about eight to 11 short leaves spirally arranged. Simple leaves, sessile or at most shortly petiolate, elliptic to oblong, flattened, with entire margin and rounded apex, $0.45 \mathrm{~cm}$ long and 0.15 $\mathrm{cm}$ wide. Leaves vascularized by a thick mid vein and another one that runs along and closely parallel to both leaf margins. 2-3 cell-wide non-stomatiferous bands of cells can be seen irregularly disposed, rectangular to quadrangular in shape, 50-70 $\mu \mathrm{m}$ length and $40-50 \mu \mathrm{m}$ width.

Remarks. The branch compression consists of a single specimen with its counterpart, and its well preserved. It is assigned to the Podocarpaceae due to the arrangement of the leaves, the shape of the lamina and the venation pattern; and to Podocarpus due to the presence of a thick midvein (Andruchow-Colombo et al., 2019; Carpenter et al., 2018). There are not many records of Podocarpaceae in the Neogene of Patagonia. In addition, the type of preservation of this compression, in axial view, makes difficult their comparison with previous records of branches in lateral view. Troncoso (1991) identifies a Podocarpus sp. 1 for the Miocene of Navidad Formation, but the leaves are very different in shape. Falaschi et al. (2012) described a fossil species cf. Podocarpus, but is not very similar either: it consists in a single leaf with a falcate shape.

Clade EUDICTOS APG, 2016

Order MYRTALES A. L. de Jussieu ex. Bercht \& J. Presl., 1789

Family MYRTACEAE A. L. de Jussieu, 1789

"Myrcia" nitens Engelhardt, 1891

(Figures 2B, F, J)

1891 Myrcia nitens Engelhardt: 671, pl. 5, fig. 10.

1928 Myrcia nitens Berry: 23, pl. 3, fig. 1-9.

1940 Myrcia nitens Fiori: 103, pl. 4, fig. 16-23.

Studied material. $\mathrm{BaPb} 16607-16633$.

Locality, unit and age. Cabo Espíritu Santo and Arroyo Beta, Tierra del Fuego, Argentina, Cullen Formation (middle Miocene).

Description. Simple leaves, nanophyll or microphyll, laminar shape elliptic or obovate with medial symmetry, $1-3.7 \mathrm{~cm}$ long and 0.3-1.4 cm wide. Apex obtuse or rounded, base symmetric and acute or obtuse, texture chartaceous, entire margin and normal petiole, short and thick. The primary venation is pinnate. Midvein stout and straight in course. The major secondaries are simple brochoidodromous, there are 5-8 pairs of secondary veins, emerging at acute angle $\left(80^{\circ}-90^{\circ}\right)$, without variation through the lamina, fines, major secondaries attachment decurrent with the midvein and straight in course. There is presence of intramarginal vein. No higher order venation preserved.

Remarks. Several specimens not well preserved. They can be assigned to "Myrcia" nitens because due to the entire margin, the simple brochidodromous secondary venation, the presence of intramarginal veins and the thick petiole characters. A great variability in the shape and size of the leaves was found, which was already documented in the species by other authors (Berry, 1928; Fiori, 1940). This species was previously identified in the Lota Coronel locality, Chile (lower Miocene) by Engelhardt (1891), and in the Nirihuau Formation (lower-middle Miocene) by Berry (1928) and Fiori (1940). These materials have the same characters as those studied in the present work.

Order FAGALES Engler, 1892

Family NOTHOFAGACEAE Kupriánova, 1962

Nothofagus Blume, 1851

Type species. Nothofagus antarctica (Forster) Oersted, 1871.

Diagnosis. See Heenan \& Smissen (2013, p. 3).

Nothofagus crenulata Dusén, 1899

(Figures 2D, H, L)

1899 Nothofagus crenulata Dusén: p. 101, pl. 10:3-4.

1986 Nothofagus crenulata Tanai: 574, pl. 15:1-4, 6, 8.

1989 Nothofagus crenulata Durango de Cabrera \& Vergel: 3, pl. 1, fig. 7 .

2017 Nothofagus crenulata Vento et al.: 5, pl. 1:D.

Studied material. $\mathrm{BaPb}$ 16580; $\mathrm{BaPb}$ 16581; $\mathrm{BaPb} 16582$.

Locality, unit and age. Cañadón de los Mineros locality, Tierra del Fuego, Cullen Formation Argentina, (middle Miocene).

Description. Simple, microphyll leaves, laminar shape elliptic with medial symmetry, 1.8 to $2.7 \mathrm{~cm}$ long and $1.2 \mathrm{~cm}$ wide. Apex obtuse, base symmetric and obtuse, crenate margin and chartaceous texture. Crenas regularly separated, with angular sinuses. The primary venation is pinnate. The midvein is thick and straight in course. The secondary venations are simple craspedodromous, there are 7-8 secondary veins, acute in angle $\left(40^{\circ}-50^{\circ}\right)$, without variation through lamina, moderate in thickness and straight, with a slightly curvature near the midvein, decurrent attachment to the midvein and regularly spaced. There are two crenas for each secondary vein, which penetrates eccentrically the crenas until the margin. It was not possible to observe higher order venation than those described. Remarks. The specimens are not well preserved. However, they can be assigned to Nothofagus crenulata because of the crenate margin, the regular disposition of the crenas and the eccentric vascularization of the secondary veins in the crenas. $N$. crenulata was already described in the Cullen Formation 

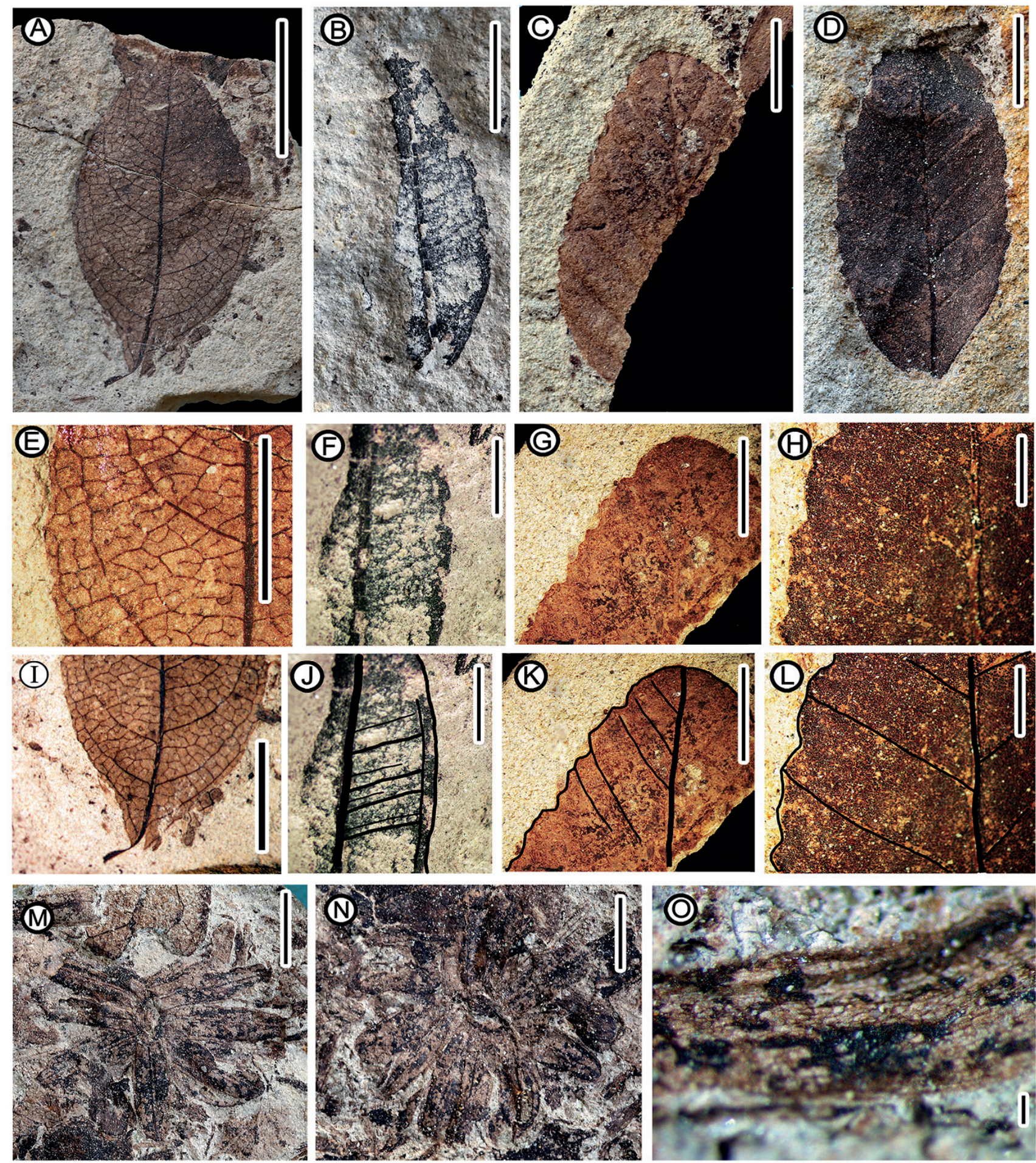

Figure 2. A, E, I, Morphotype 1, BaPb 16606. A, general view. E, I, venation detail. B, F, J, “Myrcia” nitens Engelhardt, BaPb 16610. B, general view. F, J, venation detail. C, G, K, Nothofagus densinervosa Dusén, BaPb 16634. C, general view. G, K, venation detail. D, H, L, Nothofagus crenulata Dusén, $\mathrm{BaPb}$ 16581. D, general view. H, L, venation detail. M-O, Podocarpus sp. 1, BaPb 16641. M-N, general view. O, detail of the epidermic cells. Scale bars: $1 \mathrm{~cm}$ (general view); $0.5 \mathrm{~cm}$ (venation detail).

by Durango de Cabrera \& Vergel (1989). The specimen illustrated by the authors is very similar to those studied in the present work: they have the same crenate margin, a similar disposition of the crenas and vascularization of them, and a similar leaf apex and base shape. $N$. crenulata was recognized in others Cenozoic deposits of Patagonia: Río Condor locality (upper Eocene-lower Oligocene) (Dusén 1899), Brush Lake Formation (lower Miocene) (Tanai, 1986), and Río Guillermo Formation (upper Eocene-lower Oligocene) (Gandolfo, 1994; Vento et al., 2017). A high variability in the shape of the 
lamina, apex and/or base can be observed, but the diagnostic characters of the species, related to the margin and listed above, are present in all these records.

Nothofagus densinervosa Dusén, 1899

(Figures 2C, G, K)

1899 Nothofagus densinervosa Dusén: 99, pl. 9:14-19. 1939 Nothofagus densinervosa Fiori: 67, pl. 1:18.

1941 Nothofagus densinervosa Frenguelli: 206, pl. 4:3. 1967 Nothofagus cf. densinervosa Hünicken:168, pl. 2:7. 1986 Nothofagus densinervosa Tanai: 575, pl. 12: 1-12. 2013 Nothofagus densinervosa Tosolini et al., p. 14:2K, 5B,G.

Studied material. BaPB 16634.

Locality, unit and age. Arroyo Beta, Tierra del Fuego, Cullen Formation, Argentina, middle Miocene.

Description. Simple, microphyll leave, laminar shape not observed with medial symmetrical, $3 \mathrm{~cm}$ long and $1 \mathrm{~cm}$ wide. Apex rounded, base not preserved. Margin dentate, one teeth order, convex/convex, 7 to 8 teeth/cm, regularly spaced and angular sinuses. The primary venation is pinnate. Midvein sinus thick. Major secondary veins craspedodromous. Secondaries fine in thickness, 7-8 pairs, regularly spaced, with straight course, but slightly curved near the margin, inserted at uniform acute angles $\left(40^{\circ}-50^{\circ}\right)$. Secondary veins decurrently attached to the midvein. There are two teeth for each secondary vein. One of them is vascularized by a secondary vein that penetrates the tooth eccentrically and reaches the apex. No higher order venation preserved.

Remarks. The sole specimen attributed to this fossil species is fragmented and poorly preserved. However, it can be recognized by the dentate margin, the basal penetration of the secondary veins in the teeth and the regularity of the number of teeth per secondary vein (two). Nothofagus densinervosa was previously recorded in other Patagonia outcrops: Barrancas Carmen Silva locality (lower-middle Miocene) (Dusén, 1899), Ñirihuau Formation (lower-middle Miocene) (Fiori, 1940), Río Turbio Formation (middle Eocene) (Hünicken, 1967), and Loreto Formation (upper Oligocene-lower Miocene) (Tanai, 1986). These previous records are very similar to those studied here, and share the diagnostic characters of the species that were listed above. It is worth mentioning that $N$. densinervosa was also mentioned by Frenguelli (1941) in the Río Turbio Formation, and Tosolini et al. (2013) in the Seymour islands, Antarctica, but without description or illustration.

\section{Nothofagus dicksonii (Dusén) Tanai, 1986}

(Figures 3E, H, K)

1899 Fagus dicksonii Dusén: 95, pl. 8:14-16. 1937 Fagus dicksonii Berry: 93, pl. 18:1.

1986 Nothofagus dicksonii Tanai: 577, pl. 13:4, 8, 13, 17. 2018 Nothofagus sp. cf. N. dicksonii Vento \& Prámparo: 6, pl. 4:F.
Studied material. $\mathrm{BaPb} 16583$.

Locality, unit and age. Cabo Espíritu Santo and Arroyo Beta, Tierra del Fuego, Cullen Formation, Argentina, middle Miocene.

Description. Simple, microphyll leave, laminar shape elliptic with medial symmetry, 0.9 to $1.7 \mathrm{~cm}$ long and 0.3 to $1.4 \mathrm{~cm}$. wide. Base symmetric and obtuse, margin deeply serrate and chartaceous texture. Short and narrow petiole. One order of teeth, with angular and pronounced sinuses, regularly spaced, three teeth $/ \mathrm{cm}$. The primary venation is pinnate. The midvein is moderate in thickness and straight. The major secondaries are simple craspedodromous. There are 6-8 secondary veins, acute in angle $\left(50^{\circ}-60^{\circ}\right)$, decreasing the insertion angle in the apical part of the lamina, thin in thickness, straight course, sometimes curved, and major attachment to the midvein excurrent and regularly spaced. There is one tooth per secondary vein. The principal venation of the teeth is a secondary vein that penetrates them centrally towards the apex. No higher order of venation was preserved.

Remarks. The studied specimen is not well preserved, but the diagnostic characteristics of the species are identified: high number of secondary veins (more than eight), serrate margin with one order of teeth, deep sinuses, development of a tooth by secondary veins, and central vascularization of the teeth. This species was originally included in the Fagaceae as Fagus dicksonii (Dusén, 1899), but Tanai (1986) considered that it had elements to be included in Nothofagus. It was described in different units of Patagonia and Antarctica: by Dusén (1899) in the Barrancas Carmen Silva locality (lower-middle Miocene), by Berry (1937) and Vento \& Prámparo (2018) in the Río Turbio Formation (middle Eocene), and by Tanai (1986) in the Loreto Formation (upper Oligocene-lower Miocene). The typical characters of the species listed above can be seen in the material studied here. However, there is observed more variability in the shape of the lamina and apex. $N$. dicksonii was also mentioned for the Seymour islands, Antarctica (Tosolini et al., 2013), but without illustrations or description.

\section{Nothofagus elongata (Dusén) Romero \& Dibbern, 1985} (Figures 3F, I, L)

1899 Nothofagus elongata Dusén: 97, pl. 10, figs. 12-13. 1937 Nothofagus elongata Berry: 94, pl. 18, fig. 7.

1989 Nothofagus elongata Durango de Cabrera \& Vergel: 4, pl. 1, figs. 1-2.

2011 Nothofagus elongata Panti: 324, pl. 3, figs. 5-8.

2017 Nothofagus elongata Vento et al.: p. 5, pl. 1, fig. B-C. 1967 Nothofagus cf. N. elongata Hünicken: p. 166, pl. 2, fig. 1 . 1899 Nothofagus lanceolata Dusén: s/n, pl. 8, fig. 13.

1899 Nothofagus cf. N. obliqua Mirbel Dusén: s/n, pl. 10, fig. 1.

1908 Nothofagus pulchra Dusén: p. 10, pl. 1, figs. 10, 12.

Studied materials. BaPb 16584-16589.

Locality, unit and age. Cañadón de los Mineros, Tierra del Fuego, Cullen Formation, Argentina, middle Miocene. 

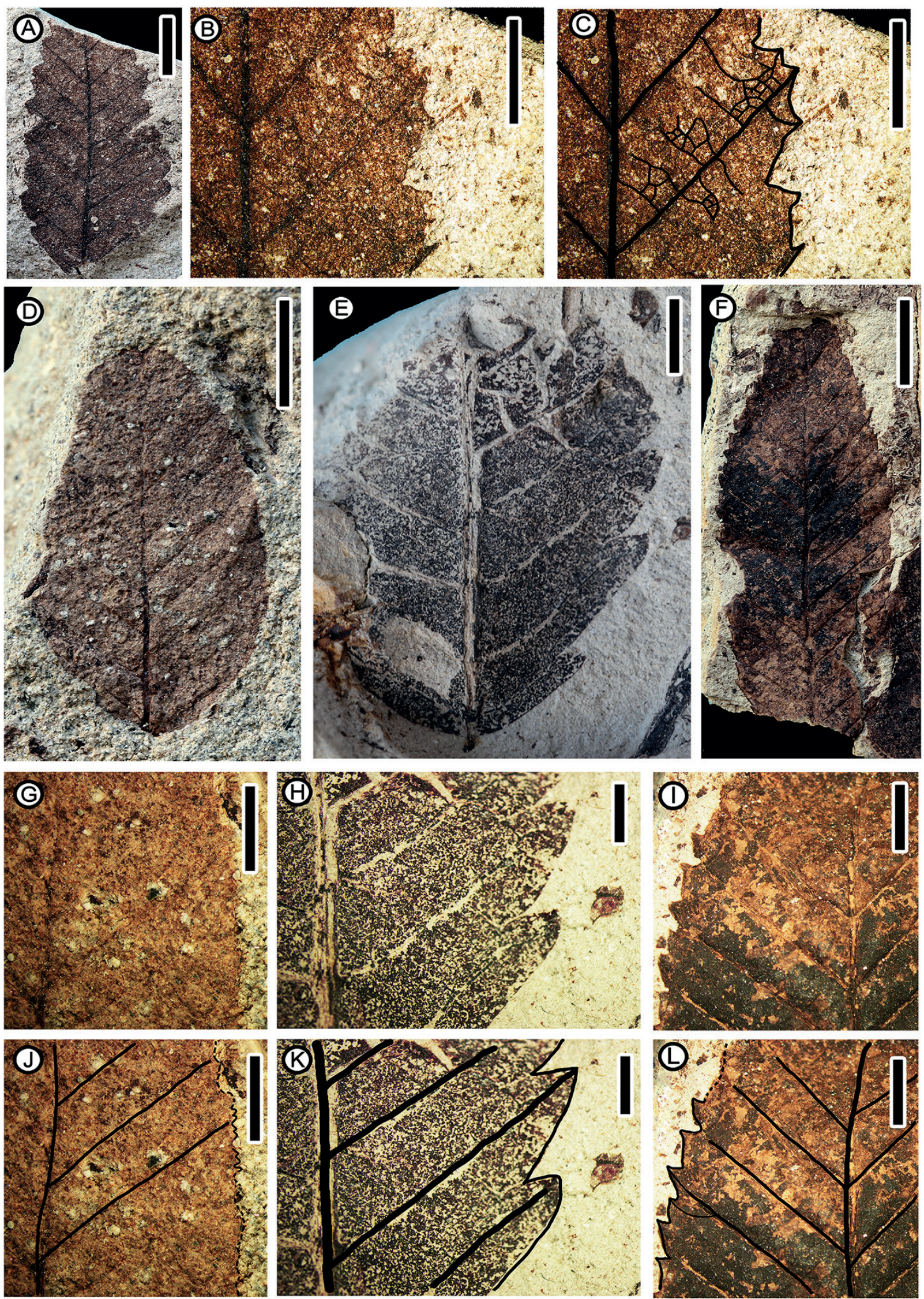

Figure 3. A-C, Nothofagus variabilis Dusén, BaPb 16604. A, general view. B, C, venation detail. D, G, J, Nothofagus serrulata Dusén, BaPb 16592 . D, general view. G, J, venation detail. E, H, K, Nothofagus dicksonii (Dusén) Tanai, BaPb 16583. E, general view. H, K, venation detail. F, I, L, Nothofagus elongata Dusén, $\mathrm{BaPb}$ 16584. F, general view. I, L, venation detail. Scale bars: $1 \mathrm{~cm}$ (general view); $0.5 \mathrm{~cm}$ (venation detail). 
Description. Simple, microphyll leaves, laminar shape ovate with medial symmetry, $10.1 \mathrm{~cm}$ high and $2.9 \mathrm{~cm}$ wide. Apex acute, margin serrate and texture chartaceous. Two orders of teeth, separated by angular sinuses, regularly spaced, teeth shape st/st and 4 to 5 teeth $/ \mathrm{cm}$. The primary venation is pinnate. The mid vein is moderate in thickness and with straight course. The major secondaries are simple craspedodromous, there are 12-16 pairs of secondary veins, acute in angle $\left(50^{\circ}-60^{\circ}\right)$, without angle variation through the lamina, thick, straight, major secondary attachment decurrent and regularly spaced. There are two teeth by secondary vein. The principal vein is a direct continuation of a secondary, which enters eccentrically along the basal side through the tooth apex. In addition, one accessory tooth is served by an outer secondary. The lamina base and higher order venation were not preserved.

Remarks. The species is recognized by the serrate margin type, with two orders of teeth, the regularity of the teeth arrangement, the basal vascularization of the teeth, the frequency of two teeth per secondary vein, and the high number of secondary veins (usually more than 10). Nothofagus elongata was already identified in the Cullen Formation (Durango de Cabrera \& Vergel, 1989). It was also recognized several other times in Patagonia: in Barrancas Carmen Silva locality (early-middle Miocene) (Dusén, 1899), Río Turbio Formation (middle Eocene) (Berry, 1937; Hünicken, 1967), Rio Guillermo Formation (upper Eocene-lower Oligocene) (Panti, 2011; Vento et al., 2017), and Nirihuau Formation (lower-middle Miocene) (Gandolfo, 1994). This species presents a high morphological variability in several characters: the shape and symmetry of the lamina, the apex and the base. However, the diagnostic characters of the species, such as the serrate margin type, two orders of teeth, regularity of the teeth arrangement, basal vascularization of the teeth, the frequency of two teeth per secondary vein, and the high number of secondary veins (usually more than 10 ), are present in all the named records.

Nothofagus serrulata Dusén, 1899

(Figures 3D, G, J)

1899 Nothofagus serrulata Dusén: 96, pl. 9, fig. 1-7.

2011 Nothofagus serrulata Panti: 324, pl. 3, fig. 12-16.

2014 Nothofagus serrulata Caviglia \& Zamaloa: 212, pl. 2, fig. 4-5.

2017 Nothofagus serrulata Vento et al.: 5, pl. 1, fig. 1.

Studied material. BaPb 16594-16603.

Locality, unit and age. Cañadón de los Mineros, Tierra del Fuego, Cullen Formation Argentina, middle Miocene.

Description. Simple, microphyll leaves, laminar shape elliptic with medial symmetry, 2.1 to $2.5 \mathrm{~cm}$ high and 1.0 to $1.3 \mathrm{~cm}$ wide. Apex rounded, base symmetric and convex. Margin serrate and texture chartaceous. One order of teeth, separated by probably angular sinuses, regularly spaced, and possibly 6 to 7 teeth $/ \mathrm{cm}$. There are four or five teeth by secondary vein.
The primary venation is pinnate. The mid vein is straight and moderate in thickness. The major secondaries are simple craspedodromous, and there are 8 to 9 pairs of secondary veins, acute in angle $\left(40^{\circ}-50^{\circ}\right)$, without angle variation thorough the lamina. Secondary veins thick, straight, major attachment decurrent and regularly spaced. Higher order venation was not preserved.

Remarks. Specimens are poorly preserved. In spite of this, the serrate margin type, the regularity of the teeth, and the high frequency of teeth by secondary veins (between three and five) allow the assignment to Nothofagus serrulata. This fossil species was identified from several Patagonian units: Barrancas Carmen Silva locality (lower-middle Miocene) (Dusén, 1899), Punta Arenas locality (upper Eocene) (Dusén, 1899), Río de las Minas (Oligocene-lower Miocene) and Brush Lake (lower Miocene) formations (Tanai, 1986), Río Guillermo Formation (upper Eocene-lower Oligocene) (Panti, 2011; Vento et al., 2017), Pico Quemado locality, Nirihuau Formation (lower-middle Miocene) (Caviglia \& Zamaloa, 2014). These records are very similar to the specimens studied here, in the serrate margin type, the regularity of the teeth, and the high frequency of teeth by secondary veins. However, there is observed a great variability in the lamina, apex and base shape.

Nothofagus variabilis Dusén, 1899 (Figures 3A-C)

1899 Nothofagus variabilis Dusén: 96, pl. 9, fig. 8-13. 1967 Nothofagus variabilis Hünicken: 167, pl. 2, fig. 3-6. 1986 Nothofagus variabilis Tanai: 579, pl. 14, fig. 3-5, 8-12, 14.

2011 Nothofagus variabilis Panti: 324, pl. 3, fig. 1-4. 2014 Nothofagus variabilis Caviglia \& Zamaloa: 212, pl. 2, fig. 8 .

2017 Nothofagus variabilis Vento et al.: 5, pl. 1, fig. F.

Studied material. BaPb 16604-16605.

Locality, unit and age. Cabo Espíritu Santo, Tierra del Fuego, Cullen Formation Argentina, middle Miocene.

Description. Simple, microphyll leaves, laminar shape ovate with slightly medial asymmetry, 2 to $3.5 \mathrm{~cm}$ high and 1.5 to $2.1 \mathrm{~cm}$ wide. The apex is not preserved (probably acute), base symmetric and obtuse, serrate margin, chartaceous texture and normal petiole $(0.6 \mathrm{~cm}$. long). Two order of teeth, with convex/convex shape, separated by angular sinuses, irregularly spaced and four teeth $/ \mathrm{cm}$. They are grouped in bigger structures, similar to crenas, with usually two inferior teeth and one superior. Primary venation pinnate. The midvein is moderate in thickness and with straight to slightly recurved course. Major secondaries are simple craspedodromous. Secondaries (7-8 pairs), opposites, emerging at acute angle $\left(40^{\circ}-50^{\circ}\right)$, without angle variation through lamina, fines, straight in course, decurrently attached and regularly spaced. A secondary vein enters by the basal side of the tooth to the apex. The inferior teeth are irrigated by outer secondaries. 
Tertiary venation percurrent opposite straight, obtuse in angle and straight course. The quaternary vein fabric is probably randomly reticulate but the preservation is not good.

Remarks. This fossil species can be identified by the serrate margin type, the two orders of teeth, the irregular arrangement of the teeth, the central vascularization of the main teeth and the number of secondary veins. Nothofagus variabilis was described several times in other Patagonian units: Barrancas Carmen Silva locality (lower-middle Miocene) (Dusén, 1899), Punta Arenas locality (late Eocene) (Dusén 1899), Río Guillermo Formation (late Eocene-early Oligocene) (Panti, 2011; Gandolfo, 1994; Vento et al., 2017), Brush Lake Formation (lower Miocene) in the Río Chico locality, and the Loreto Formation (Oligocene-lower Miocene) at Río de las Minas locality (Tanai, 1986), Río Turbio Formation (middle Eocene) (Berry, 1937; Hünicken, 1967), and Ñirihuau Formation (lower-middle Miocene) (Caviglia \& Zamaloa, 2014). It can be observed high variability in the leaf, apex and/or base shape, but diagnostic characters of the species, listed earlier, are present in all these records.

\section{Order LAMIALES Bromhead, 1838 \\ Family GESNERIACEAE Richard \& Jussieu, 1816}

\section{Morphotype 1 \\ (Figures 2A, E, I)}

\section{Studied material. $\mathrm{BaPb} 16606$.}

Locality, unit and age. Cañadón de los Mineros, Tierra del Fuego, Cullen Formation. Argentina, middle Miocene.

Description. Simple leaf, nanophyll, laminar shape elliptic with medial symmetry, $1.5 \mathrm{~cm}$ high and $0.9 \mathrm{~cm}$ wide. Apex obtuse, base asymmetric and cuneate, margin serrated, petiole normal and thin $(0.1 \mathrm{~cm}$ long). One order of teeth, teeth present only between the medial and proximal part of the leave, straight/straight in shape, separated by angular sinuses, irregularly spaced, strongly apically oriented and five teeth/cm. The principal venation is semicraspedodromous. The midvein is stout and with recurved course. Six pairs of secondary veins, fine, base angle acute, without angle variation through the lamina, recurved in course, major attachment to the midvein decurrent and regularly spaced. There are two or three teeth per secondary vein. An exterior tertiary vein penetrates the tooth until the apex. Intersecondary veins perpendicular to midvein, distal course parallel to the major secondaries, usually one per intercostal area. Tertiary veins percurrents opposite straight, acute in angle and sinuous course. Epimedial tertiaries are percurrent, perpendicular to the subjacent secondary proximally. Exterior tertiaries ending at the margin. Quaternary vein fabric is irregularly reticulate, thin. Quinternary vein fabric is freely ramifying. There is a moderate development of areolation, and the freely ending veinlets are mostly with one branch, simple terminals.

Remarks. Although it consists of only one specimen, it shows characteristics that allow it to be recognized as a distinctive morphotype. It is characterized by the asymmetric base, the normal petiole, the serrate margin, the one order teeth and the semicraspedodromous secondary veins arrangement. It was included in the Gesneriaceae due to the similarity with the extant Mitraria coccinea Cavanilles \& Palop. Both have an elliptic leaf shape, rounded apex and straight and asymmetric base, the presence of teeth in the superior part of the lamina, the irrigation of the teeth by exterior tertiaries, the few secondary number, thin secondary veins in relation with the primary vein, and secondary veins semicraspedodromous. However, they differ in the lower density of the tertiary veins, the freely ramifying disposition of the quaternary veins, and the teeth size considerably larger in $M$. coccinea than the fossil specimen studied in the present work. Troncoso (1991) described cf. Mitraria sp. in the Navidad Formation (middle Miocene). However, it has several differences with the fossil taxon described here: it has a symmetrical base, a thick and straight midvein, very large teeth along the entire lamina and craspedodromous secondary venation.

\section{DISCUSSION}

\section{Characterization of the flora}

Six species of Nothofagus and one representative of the families Myrtaceae, Gesneriaceae and Podocarpaceae were recognized in the association studied (Table 2). These results expand the knowledge of the megaflora in the unit. Dusén (1899) recognized two Nothofagus fossil species ( $N$. densinervosa and $N$. simplicidens) from the Cullen Formation. $N$. densinervosa was identified in the present work, and some remains found could represent fragments of $N$. simplicidens, but given their poor preservation, they were not assigned to any taxon. Later, Durango de Cabrera \& Vergel (1989) described four species from the Cullen Formation: Nothofagus crenulata, N. elongata, $N$. simplicidens and Fagus integrifolia. Both $N$. crenulata and N. elongata were found and described in the present work. However, F. integrifolia is a dubious fossil species according to Tanai (1986), and no assignable remains were found.

Palma et al. (1992) mentioned the presence of foliar remains assignable to Nothofagaceae, Myrtaceae, Araucariaceae, Podocarpaceae and Fagaceae in the Cullen Formation, but without providing illustrations or descriptions. We found some remains attributable to Araucariaceae, but the preservation is too fragmentary and does not allow identification. Tanai (1986) questioned all assignments included in Fagus that were made based on fossil foliar remains from outcrops in Patagonia. Therefore, it is possible that those mentioned in Palma et al. (1992) belong to Nothofagus. A review of the specimens is needed to confirm these affinities. Finally, Gandolfo (1994) identified and described N. elongata, $N$. simplicidens and $N$. australis of the Cullen Formation, but no specimen resembling $N$. australis was identified in the present study.

In the Cullen Formation, the development of a diverse flora has been proposed according to several palynological studies (Table 2): around 30 families of angiosperms, three families of conifers and a diverse set of bryophytes, ferns, algae and 
fungi were identified (Durango de Cabrera \& Vergel, 1998; Zamaloa, 1996, 1999, 2000, 2004, 2005; Zetter et al., 2000; García-Massini et al., 2004). In addition, the predominance of Nothofagaceae species in the palynological assemblages was noticed (Zamaloa, 1999, 2000, Zetter et al., 2000). According to the megaflora studied in the present work, it was also observed the predominance of fossil species of Nothofagus, and the presence of Myrtaceae and Podocarpaceae that was previously documented by pollen grains (Zamaloa, 1999, 2000). On the other hand, the fossil leaf related to the Gesneriaceae is the first record for the family in the unit.

Based on the microflora, the paleoenvironment of the Cullen Formation was interpreted as a multi-layered closed forest that grew in cold temperate humidity conditions and semi-permanent fresh water bodies developed locally. (Zamaloa, 2000, 2004; García-Massini et al., 2004). The megafloristic elements found support these proposed characteristics. The Nothofagus spp. dominance agrees with a cold temperate climate, and both Myrtaceae and Gesneriaceae correspond with humid environments. Myrtaceae is a family that is distributed mainly in the tropical environments represented in the north of Argentina, and that presents a good fossil record in Patagonia, usually associated with warm environments (Panti, 2016, 2018). Gesneriaceae (150-160 genera, 3200 species) is a clade mainly integrated by tropical or subtropical taxa, but with some temperate species, with perennial herbaceous forms, shrubs or small trees from South America, Africa, Europe and Australia (Woo et al., 2011; Perret et al., 2012). Although both families have a major tropical distribution, some elements can be found in cold or temperate environments (Panti, 2018; Perret et al., 2012).

According to the floristic types proposed by Troncoso \& Romero (1998), the Cullen Formation association could be characterized as Subantartic. The different floristic types proposed by these authors are based on the paleofloristic composition. The Subantartic paleofloras were dominant during late Oligocene-early Miocene, and are distinguished by the dominance of Nothofagaceae, together with other austral elements and a low proportion of tropical or subtropical components. Hinojosa (2005), based on leaf physiognomic analyses, made a different categorization of Cenozoic paleofloras and did not recognize the presence of the Subantartic paleofloras in Patagonia. The author proposed the development of Neogene Subtropical paleofloras during the Miocene, characterized by the prevalence of warm taxa. However, this characterization would not be adequate for the Cullen Formation, considering that both megafloristic and pollen records shows the Nothofagaceae dominance, and the important presence of other typical austral elements like Podocarpaceae and Proteaceae (Zamaloa, 2000). In addition, the pollen record also suggests an environment with high levels of humidity (Zamaloa, 1999, 2000; Zetter et al., 2000; García-Massini et al., 2004), which is concordant with the megafloristic record studied in the present work.
Recent studies suggest that the presence of typical tropical/subtropical families in the paleofloras developed in the Miocene of Patagonia was more important than what Troncoso \& Romero (1998) proposed in their definition of Subantartic floristic types (Barreda et al., 2007; Palazessi \& Barreda, 2007; Quattrocchio et al., 2013). Although the characterization of Hinojosa (2005) is not adequate for the paleoflora of Cullen Formation, his analyses also proposed an important development of warm elements during the Miocene in Patagonia. Zachos et al. (2001) proposed an increase in temperature throughout the world since the late Eocene to the middle Miocene, which would have had a positive impact on the development of the Patagonian floras (Hinojosa et al., 2011; Le Roux, 2012a,b; Caviglia, 2018). This information allows characterizing in more detail the paleoflora developed in the Cullen Formation; although it is certain that the most adequate characterization is the Subantartic floristic type sensu Troncoso \& Romero (1998), the important presence of tropical/subtropical elements must also be considered, especially considering the pollen record (Zamaloa, 2000). As previously proposed, the Cullen Formation would have been developed under a warmer environment than today (Zamaloa, 2004).

\section{Comparisons with others floras}

A cluster analysis was made with all the recorded paleofloras that developed during the Miocene in Patagonia, comparing the absence/presence of plant families (Figure 4). The results show that the paleoflora developed in the Cullen Formation is most similar to the ones from Rio Leona, Ñirihuau and Santa Cruz formations, and Arroyo de los Ciervos locality (Figure 4). The most similar paleofloras developed a floral association comparable to the one of the Cullen Formation. All of them show an important presence of Nothofagaceae, with other typical Antartic taxa, but also the existence of tropical or subtropical families (Dusén, 1899; Fiori, 1931, 1939, 1940; Troncoso, 1991; Brea et al., 2012; Césari et al., 2015; Pujana et al., 2015). The list of families identified in each paleoflora is shown in Table 3. In addition, some of the paleofloras were also included in the Subantartic floristic type, such as Barrancas Carmen Silva, Nirihuau and Río Leona (Troncoso \& Romero, 1998; Césari et al., 2015; Caviglia, 2018). In any case, a low similarity was observed with the paleoflora of Barrancas Carmen Silva locality, which developed in an age and latitude similar of Cullen Formation. This may be due to the small number of families identified in it (Table 3). On the contrary, the paleoflora developed in the Navidad Formation also shows a low similarity; in this case, perhaps due to the large number of identified families.

In conclusion, the leaf association from Cullen Formation studied in the present work agrees with the development of the paleofloras during the early Neogene in Patagonia (Hinojosa, 2005; Barreda et al., 2007, Barreda \& Palazzesi, 2007), and it was found similar to the paleofloras developed at the same time. 


\section{$\begin{array}{lllllllll}0.1 & 0.2 & 0.3 & 0.4 & 0.5 & 0.6 & 0.7 & 0.8 & 0.9\end{array}$}

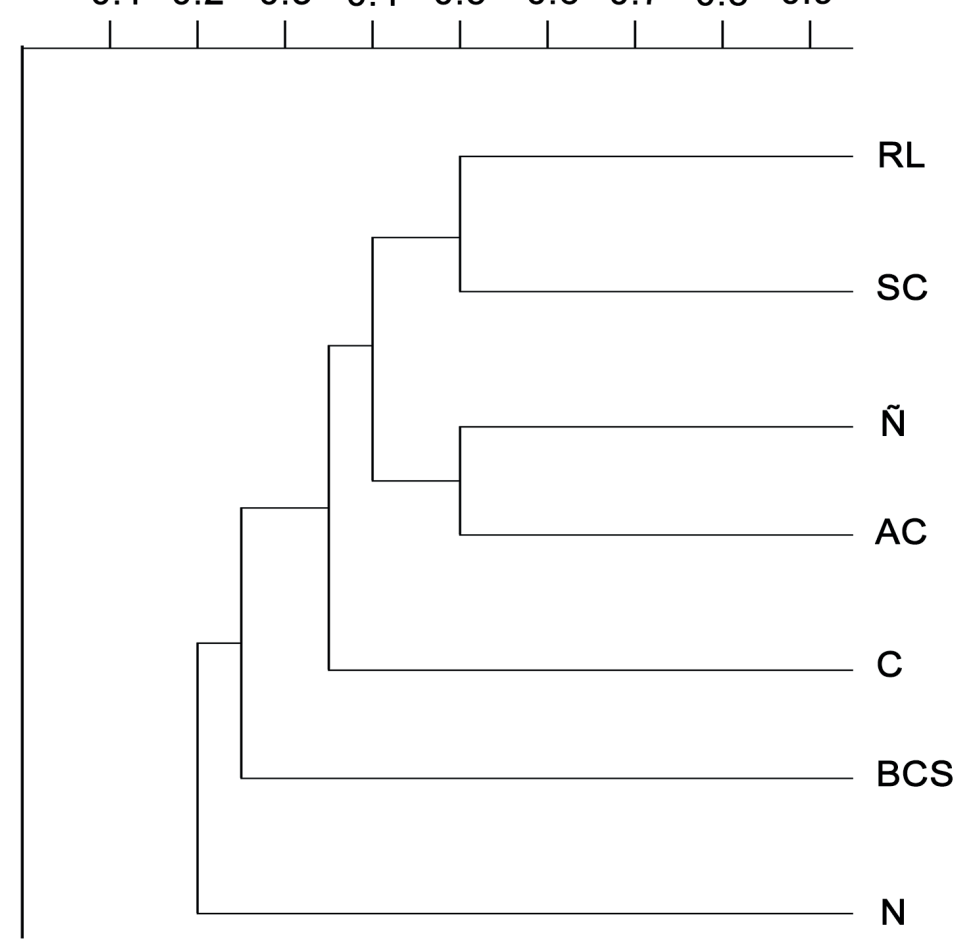

Figure 4. Cluster analysis with Jaccard index. Abbreviations: RL, Río Leona Formation; SC, Santa Cruz Formation; 林, Nirihuau Formation; AC, Arroyo de los Ciervos locality; C, Cullen Formation; BCS, Barrancas Carmen Silva locality; N, Navidad Formation.

Table 3. Families diversity in megafloras developed during the Neogene in Patagonia. Based on Dusén (1899), Fiori (1931, 1939, 1940), Troncoso (1991), Brea et al. (2012), Césari et al. (2015), Pujana et al. (2015) and the present work.

\begin{tabular}{|c|c|c|c|c|c|c|}
\hline Navidad Fm. & Río Leona Fm. & Ñirihuau Fm. & Cullen Fm. & $\begin{array}{l}\text { Barrancas Carmen } \\
\text { Silva locality }\end{array}$ & Santa Cruz Fm. & $\begin{array}{l}\text { Arroyo de los } \\
\text { Ciervos locality }\end{array}$ \\
\hline Equisetaceae & Anacardiaceae & Araucariaceae & Podocarpaceae & Nothofagaceae & Cunoniaceae & Araucariaceae \\
\hline Asplinaceae & Fabaceae & Podocarpaceae & Gesneriaceae & & Fabaceae & Podocarpaceae \\
\hline Aspidiaceae & Lauraceae & Fabaceae & Myrtaceae & & Lauraceae & Cupressaceae \\
\hline Blechnaceae & Myrtaceae & Myricaceae & Nothofagaceae & & Myrtaceae & Fabaceae \\
\hline Lophosoriaceae & Nothofagaceae & Myrtaceae & & & Nothofagaceae & Lauraceae \\
\hline Araucariaceae & Rosaceae & Nothofagaceae & & & Proteaceae & Nothofagaceae \\
\hline Berberidaceae & & Rosaceae & & & & Rosaceae? \\
\hline Cunoniaceae & & & & & & Typhaceae \\
\hline \multicolumn{7}{|l|}{ Dioscoreaceae } \\
\hline \multicolumn{7}{|l|}{ Fabaceae } \\
\hline \multicolumn{7}{|l|}{ Gesneriaceae } \\
\hline \multicolumn{7}{|l|}{ Lardizabalaceae } \\
\hline \multicolumn{7}{|l|}{ Lauraceae } \\
\hline \multicolumn{7}{|l|}{ Loganiaceae } \\
\hline \multicolumn{7}{|l|}{ Malpighiaceae } \\
\hline \multicolumn{7}{|l|}{ Melastomataceae } \\
\hline \multicolumn{7}{|l|}{ Monimiaceae } \\
\hline \multicolumn{7}{|l|}{ Myrtaceae } \\
\hline \multicolumn{7}{|l|}{ Nothofagaceae } \\
\hline \multicolumn{7}{|l|}{ Podocarpaceae } \\
\hline Thymelaeceae & & & & & & \\
\hline
\end{tabular}




\section{CONCLUSIONS}

Over 200 leaf impressions from the Cullen Formation were studied. They were identified one species of Podocarpus, six of Nothofagus, one of "Myrcia", and a fossil taxon related to Gesneriaceae, which represents the first record of this family in Argentina. These results extend the megafloral record of Cullen Formation. In addition, the association studied coincides with the climatic variables suggested for the unit that were carried out based on the characterization of the microflora: the Cullen Formation was probably developed under a cold temperate climate, although with probably high levels of humidity. The comparison with other contemporary paleofloras developed in Patagonia revealed similar floristic assemblages, with Nothofagaceae as the dominant group, and the presence of some tropical/subtropical taxa. According to its composition, the paleoflora of the Cullen Formation is characterized as Subantartic sensu Troncoso \& Romero (1998).

\section{ACKNOWLEDGMENTS}

The fossils studied here were collected in several fields trip by M.d.C. Zamaloa, M.A. Gandolfo, E. Romero and R. Palma. I also want to thank E. Vera and M. Passalia for the corrections made in the manuscript, and G. del Fueyo, paleobotanic curator of the Museo Argentino de Ciencias Naturales "Bernardino Rivadavia". Finally, I like to thank the reviewers of this work.

\section{REFERENCES}

Andruchow-Colombo, A.; Escapa, I.; Carpenter, R.J.; Hill, R.S.; Iglesias, A.; Abarzua, A.M. \& Wilf, P. 2019. Oldest record of the scale-leaved clade of Podocarpaceae, early Paleocene of Patagonia, Argentina. Alcheringa, 43:127-145. doi:10.1080/03115518.2018.1517222

APG IV. 2016. An update of the Angiosperm Phylogeny Group classification for the orders and families of flowering plants: APG IV. Botanical Journal of the Linnean Society, 181:1-20. doi:10.1111/boj.12385

Archangelsky, S. 2005. La paleobotánica en Argentina y su desarrollo durante los últimos 50 años. Buenos Aires, Asociación Paleontológica Argentina, p. 37-49 (Publicación Especial 10).

Barreda, V.D.; Palazzesi, L.; Katinas, L.; Crisci, J.V.; Tellería, M.C.; Bremer, K.; Passalía, M.G.; Bechis, F. \& Corsolini, R.R. 2011. An extinct Eocene taxon of the daisy family (Asteraceae): evolutionary, ecological and biogeographical implications. Annals of Botany, 109:127-134. doi:10.1093/aob/mcr240

Bengston, P. 1988. Open nomenclature. Palaeontology, 31:223-227.

Berry, E.W. 1928. Tertiary fossil plants from the Argentine Republic. Proceedings US National Museum, 73:1-27.

Berry, E.W. 1937. Eocene plants from Río Turbio in the territory of Santa Cruz, Patagonia. Contribution to Paleobotany of South America. John Hopkins Studies in Geolology, 12:91-97.

Brea, M.; Zucol, A.F. \& Iglesias, A. 2012. Fossil plant studies from late Early Miocene of the Santa Cruz Formation: paleoecology and paleoclimatology at the passive margin of Patagonia,
Argentina. In: S.F. Vizcaíno; R.F. Kay \& M.S. Bargo (eds.) Early Miocene paleobiology in Patagonia: highlatitude paleocommunities of the Santa Cruz Formation, Cambridge University Press, p. 104-128. doi:10.1017/ CBO9780511667381.008

Carpenter, R.J.; Iglesias, A. \& Wilf, P. 2018. Early Cenozoic vegetation in Patagonia: new insights from organically preserved plant fossils (Ligorio Márquez Formation, Argentina). International Journal Plant of Sciences, 179:115-135. doi:10.1086/695488

Caviglia, N. 2014. Morphological analyses of a Miocene paleoflora, from Tierra del Fuego, Argentina. In: INTERNATIONAL PALEONTOLOGICAL CONGRESS, 4, 2014. Abstracts, Mendoza, IPA, p. 502.

Caviglia, N. 2017. Análisis morfológico, fitogeográfico y fisonómico de una paleoflora del Mioceno de Tierra del Fuego, Argentina. Universidad de Buenos Aires, PhD thesis, 194 p.

Caviglia, N. 2018. Early Miocene climate estimations in Patagonia: the case of Pico Quemado, Nirihuau Formation (Lower-Middle Miocene). Journal of South American Earth Sciences, 88:64-71. doi:10.1016/j.jsames.2018.08.002

Caviglia, N. \& Zamaloa, M.C. 2014. Flora angiospérmica de Pico Quemado, Formación Ñirihuau (Oligoceno tardío), Provincia de Río Negro, Argentina. Ameghiniana, 51:209-225. doi:10.5710/ AMGH.24.02.2014.800

Césari, S.N.; Panti, C.; Pujana, R.R.; Francis, J.E \& Marenssi, S. 2015. The Late Oligocene flora from the Río Leona Formation, Argentinian Patagonian. Review of Palaeobotany and Palynology, 216:143-158. doi:10.1016/j.revpalbo.2015.01.002

Codignotto, J.O. \& Malumián, N. 1981. Geología de la región al Norte del paralelo $54^{\circ} \mathrm{S}$. de la Isla Grande de Tierra del Fuego. Revista de la Asociación Geológica Argentina, 36:44-88.

Darwin, C.R. 1848. Geological observations on South America. Being the third part of the geology of the voyage of the Beagle, under the command of Capt. Fitzroy, R.N. during the years 1832 to 1836. London, Smith Elder and Co.

Di Benedetto, H. 1973. Cuadro de correlación estratigráfica de Cuenca Austral. Buenos Aires, Y.P.F., 13 p.

Durango de Cabrera, J. \& Vergel, M.M. 1989. Contribución al conocimiento de las hojas de Fagaceae de la Formación Cullen, Terciario del territorio nacional de Tierra del Fuego, República Argentina. Acta Geológica Lilloana, 17:549-565.

Dusén, P. 1899. Über die tertiäre Flora der Magellanslander. Wissenchtaftiche. Ergebnisse der Schwedischen, 1:84-107.

Ellis, B.; Daly, D.; Hickey, L.J.; Johnson, K.R.; Mitchell, J.D.; Wilf, P. \& Wing, S.L. 2009. Manual of leaf architecture. New York, University Press, $190 \mathrm{p}$.

Engelhardt, H. 1891. Über Tertiärpflanzen von Chile. Abhandlungen der Senckenbergischen Natur forschenden Gessellschaft, 16:629-692.

Fiori, A. 1931. Fillite terziare della Patagonia. I. Fillite della riva meridionalle del Lago Nahuel Huapí. Giornale di Geologia, 6:101-116.

Fiori, A. 1939. Fillite terziare della Patagonia. II. Fillite del Río Nirihuau. Giornale di Geologia, 13:1-27.

Fiori, A. 1940. Fillite terziare della Patagonia. III. Fillite del Río Chenqueniyeu. Giornale di Geologia, 14:93-133.

Frenguelli. J. 1941. Nuevos elementos florísticos del Magellaniano de Patagonia austral. Notas del Museo de La Plata, 6:173-202.

Gandolfo, M.A. 1994. Evolución del género Nothofagus Blume basada en su morfología foliar comparada. Universidad de Buenos Aires, PhD thesis, 159 p. 
García-Massini, J.L.; Zamaloa, M.C. \& Romero, E.J. 2004. Fungal fruiting bodies in the Cullen Formation (Miocene) in Tierra del Fuego, Argentina. Ameghiniana, 41:83-90.

Hickey, L. 1973. Classification of the architecture of dicotyledonous leaves. American Journal of Botany, 60:17-33. doi:10.1002/j.1537-2197.1973.tb10192.x

Hinojosa, L.F. 2005. Cambios climáticos y vegetacionales inferidos a partir de paleofloras cenozoicas del sur de Sudamérica. Revista Geológica de Chile, 32:95-115. doi:10.4067/S071602082005000100006

Hinojosa, L.F.; Pérez, F.; Gaxiola, A. \& Sandoval, I. 2011. Historical and phylogenetic constraints on the incidence of entire leaf margins: insights from a new South American model. Global Ecology and Biogeography, 20:380-390. doi:10.1111/j.14668238.2010.00595.x

Huff, P.M.; Wilf, P. \& Azumah, E.J. 2003. Digital future for paleoclimate estimation from fossil leaves? Preliminary results. Palaios, 18:266-274. doi:10.1669/0883-1351 (2003)018<0266:DFFPEF>2.0.CO;2

Hünicken, M. 1967. Flora terciaria de los estratos de Río Turbio, Santa Cruz (Níveles plantíferos del Arroyo Santa Flavia). Revista Facultad de Ciencias Exactas, Físicas y Naturales, 27:139-260.

Iglesias, A.; Wilf, P.; Johnson, K.R.; Zamuner, A.B.; Cúneo, N.R.; Matheos, S.D. \& Singer, B.S. 2007. A Paleocene lowland macroflora from Patagonia reveals significantly greater richness than North American analogs. Geology, 35:947-950. doi: $10.1130 / G 23889 A .1$

Le Roux, J.P. 2012a. A review of Tertiary climate changes in southern South America and the Antarctic Peninsula. Part 1: Oceanic conditions. Sedimentary Geology, 247-248:1-20. doi:10.1016/j. sedgeo.2011.12.014

Le Roux, J.P. 2012b. A review of Tertiary climate changes in southern South America and the Antarctic Peninsula. Part 2: Continental conditions. Sedimentary Geology, 247-248:21-38. doi:10.1016/j.sedgeo.2011.12.001

Ottone, E.G. 2005. The history of palaeobotany in Argentina during the $19^{\text {th }}$ century. In: A.J. Bowden; C.V. Burek \& E. Wilding (eds.) History of palaeobotany: selected essays, London, The Geological Society, p. 281-294 (Special Publications 241). doi:10.1144/GSL.SP.2003.207.01.18

Ottone, E. G. 2011. Historia de la paleobotánica en la Argentina durante el siglo XIX: científicos, exploradores y el país en exposición. Revista de la Asociación Geológica Argentina, 68:370-379.

Palazzesi, L. \& Barreda, V. 2007. Major vegetation trends in the Tertiary of Patagonia (Argentina): A qualitative paleoclimatic approach based on palynological evidence. Flora, 202:328-337. doi:10.1016/j:flora.2006.07.006

Palma, R.M.; Zamaloa, M.C. \& Gandolfo, M.A. 1992. Depósitos de la Formación Cullen y su contenido paleontológico, Terciario de Tierra del Fuego. In: REUNIÓN ARGENTINA DE SEDIMENTOLOGÍA, 4, 1992. Actas, Tucumán, AAS, p. 271-278.

Panti, C. 2011. Análisis paleoflorístico de la Formación Río Guillermo (Eoceno tardío-Oligoceno temprano?), Santa Cruz, Argentina. Ameghiniana, 48:320-335.

Panti, C. 2016. Myrtaceae fossil leaves from the Río Turbio Formation (Middle Eocene), Santa Cruz Province, Argentina. Historical Biology, 28:459-469. doi:10.1080/08912963. 2014.976635

Panti, C. 2018. Fossil leaves of subtropical lineages in the Eocene?Oligocene of southern Patagonia. Historical Biology, in press. doi:10.1080/08912963.2018.1487421
Panti, C.; Marenssi, S.A. \& Olivero, E.B. 2008. Paleogene flora of the Slogget Formation, Tierra del Fuego, Argentina. Ameghiniana, 45:667-692.

Perret, M.; Chautems, A.; Araujo, A.O. \& Salamin, N. 2012. Temporal and spatial origin of Gesneriaceae in the New World inferred from plastid DNA sequences. Botanical Journal of the Linnean Society, 171:61-79. doi:10.1111/j.1095-8339.2012.01303.x

Petersen, C.S. \& Methol, E.J. 1948. Nota preliminar sobre rasgos geológicos generales de la porción septentrional de Tierra del Fuego. Revista de la Asociación Geológica Argentina, 3:279-291.

Pujana, R.R.; Panti, C.; Cuitiño, J.I.; García-Massini, J.L. \& Mirabelli, S.L. 2015. A new megaflora (fossil wood and leaves) from the Miocene of southwestern Patagonia. Ameghiniana, 52:350-366. doi:10.5710/AMGH.05.01.2014.2805

Quattrocchio, M.E.; Martínes, M.A.; Hinojosa, L.F., \& Jaramillo, C. 2013. Quantitative analysis of Cenozoic palynofloras from Patagonia, southern South America. Palynology, 37:246-258. doi:10.1080/01916122.2013.787126

R Development Core Team, 2017. R: A language and environment for statistical computing. Vienna, R Foundation for Statistical Computing.

Romero, E.J. 1978. Paleoecología y Paleofitogeografía de las tafofloras del Cenofítico de Argentina y áreas vecinas. Ameghiniana, 15:209-227.

Romero, E.J. \& Argüijo, M.H. 1981. Análisis bioestratigráfico de las tafofloras del Cretácico Superior de Austro-Sudamérica. Comité sudamericano del Jurásico y Cretácico: cuencas sedimentarias del Jurásico y Cretácico de América del Sur, 2:393-406.

Romero, E.J. \& Dibbern, M.C. 1985. A review of the species described as Fagus and Nothofagus by Dusén. Palaeontographica Abteilung B, 197:123-137.

Russo, A.; Flores, M.A. \& Di Benedetto, H. 1980. Patagonia Austral Extraandina. Academia Nacional de Ciencias, 2:1431-1462.

Tanai, T. 1986. Phytogeographic and phylogenetic history of the genus Nothofagus B1. (Fagaceae) in the Southern hemisphere. Journal Faculty of Sciences, 4:505-582.

Tosolini, A.M.; Cantrill, D. \& Francis, J. 2013. Paleocene flora from Seymour Island, Antarctica: Revision of Dusén's (1908) angiosperm taxones. Alcheringa, 37:366-391. doi:10.1080/ 03115518.2013 .764698

Troncoso, A.A. 1991. Paleomegaflora de la Formación Navidad, Miembro Navidad (Mioceno), en el área de Matanzas, Chile central occidental. Boletín Museo Nacional Historia Natural Chile, 42:131-168.

Troncoso, A. \& Romero, E.J. 1998. Evolución de las comunidades florísticas en el extremo sur de sudamérica durante el cenofítico. In: CONGRESO LATINOAMERICANO DE BOTANICA, 6, 1998. Proceedings, Mar del Plata, p. 149-172.

Vento, B.; Gandolfo, M.A.; Nixon, K.C. \& Prámparo, M. 2017. Paleofloristic assemblage from the Paleogene Río Guillermo Formation, Argentina, preliminary results of phylogenetic relationships of Nothofagus in South America. Historical Biology, 29:90-107. doi:10.1080/08912963.2015.1136930

Vento, B. \& Prámparo, M. 2018. Angiosperm association from the Río Turbio Formation (Eocene-?Oligocene) Santa Cruz, Argentina: revision of Hünicken's (1955) fossil leaves collection. Alcheringa, 42:125-133. doi:10.1080/03115518.2017.1408854

Vergel, M.M. \& Durango de Cabrera, J. 1988. Palinología de la Formación Cullen (Terciario) de las inmediaciones de Cañadón Beta, Tierra del Fuego, República Argentina. In: CONGRESO GEOLÓGICO CHILENO, 4, 1985. Actas, Antofagasta, p. 227-245. 
Wilf, P.; Cúneo, N.R.; Johnson, K.R.; Hicks, J.F.; Wing, S.L. \& Obradovich, J.D. 2003. High plant diversity in Eocene South America: evidence from Patagonia. Science, 300:122-125. doi:10.1126/science.1080475

Wilf, P.; Johnson, K.R.; Cúneo, N.R.; Smith, M.E.; Singer, B.S. \& Gandolfo, M.A. 2005. Eocene plant diversity at Laguna del Hunco and Río Pichileufú, Patagonia, Argentina. American Naturalist, 165: 634-650. doi:10.1086/430055

Woo, V.L.; Funke, M.M.; Smith, J.F.; Lockhart, P.J. \& GarnockJones, P.J. 2011. New World origins of Southwest Pacific Gesneriaceae: multiple movements across and within the South Pacific. International Journal of Plant Sciences, 172:434-457. doi:10.1086/658183

Zachos, J.; Pagani, M.; Sloan, L.; Thomas, E. \& Billups, K. 2001. Trends, rhythms and aberrations in global climate $65 \mathrm{Ma}$ to present. Science, 292:686-693. doi:10.1126/science.1059412

Zamaloa, M.C. 1996. Asociación de zigósporas de Zygnemataceae (Chlorophyta) en el Terciario medio de Tierra del Fuego, Argentina. Ameghiniana, 33:179-184.

Zamaloa, M.C. 1999. Estudio palinológico de la Formación Cullen (Terciario Superior), Tierra del Fuego, Argentina. Universidad de Buenos Aires, $\mathrm{PhD}$ thesis, $243 \mathrm{p}$.

Zamaloa, M.C. 2000. Palinoflora y ambiente en el Terciario del nordeste de Tierra del Fuego, Argentina. Revista del Museo Argentino de Ciencias Naturales, 2:43-51.
Zamaloa, M.C. 2004. Miocene algae and spores from Tierra del Fuego, Argentina. Alcheringa, 28:205-227. doi:10.1080/03115510408619282

Zamaloa, M.C. \& Romero, E.J. 1990. Some spores and pollen from the Cullen Formation (Upper Eocene to Middle Oligocene), Tierra del Fuego, Argentina. Palynology, 14:123-133. doi:10.1080/01916122.1990.9989376

Zamaloa, M.C. \& Romero, E.J. 2005. Neogene palynology of Tierra del Fuego, Argentina: conifers. Alcheringa, 29:113-121. doi:10.1080/03115510508619563

Zetter, R.; Hoffman, C.; Draxler, I.; Durango de Cabrera, J.; Vergel, M. \& Verboorst, E. 2000. A rich Middle Eocene Microflora at Arroyo de los Mineros, near Cañadón Beta, NE Tierra del Fuego Province, Argentina. Abhandlungen der Geolgischen Bundesanstalt, 56:439-460.

Received in 10 April, 2019; accepted in 22 July, 2019. 


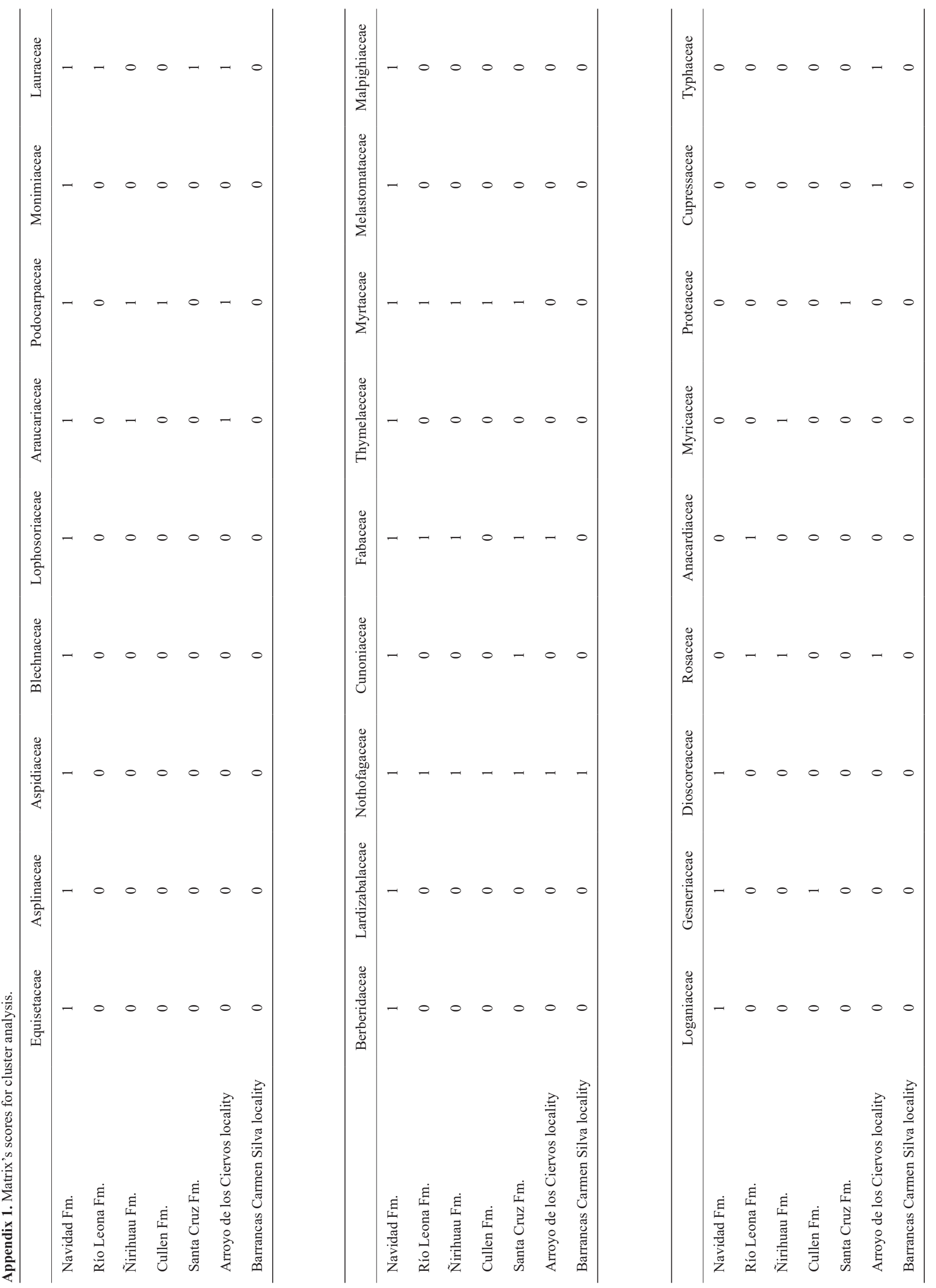

